\title{
Ekonomia polityczna lalek
}

\author{
Ryszard KozioŁeK \\ (Uniwersytet Śląski w Katowicach)
}

Osłabiony autorytet narratora w Lalce prowokuje czytelnika do całkowitego sceptycyzmu. Żadna wypowiedź postaci lub narratorów powieści nie zasługuje na jego pełne zaufanie. Relatywne, subiektywne, często stronnicze są w powieści sądy, relacje i diagnozy, nie mówiąc już o plotkach i pogłoskach. Osłabienie poziomu faktyczności w powieści wcale jednak nie przeczy prawdopodobieństwu przedstawienia. Oznacza natomiast, że kłamliwe lub wątpliwe informacje o świecie powieściowym nie muszą naruszać wiarygodności w ukazywaniu zasad komunikowania w utworze i przekazywania w nim wiedzy o świecie, jaką dysponują postacie. Przykładem mogą być sprzeczne sądy o śmierci Małgorzaty Mincel czy niezliczone wersje biografii Wokulskiego ${ }^{\mathrm{I}}$. Fenomenalne wykorzystanie przez Prusa perspektywizmu poznawczego oznacza, że prawda czy po prostu racja nie spoczywa $\mathrm{w}$ depozycie narratora lub postaci wiodącej; przeciwnie, często sądy postaci „słabej” pod względem posiadanej przez nią wiedzy okazują się najcelniejsze.

Dalsza praca analityczna wynika właśnie z takiego zlekceważenia postaci, powinna więc być utrzymana w regułach gatunku lub przynajmniej w tonie samokrytyki ${ }^{2}$. Otóż wyznaję, że dwukrotnie zwątpiłem w Bolesława Prusa - raz w niego samego, drugi raz - w jego postać. Pierwsze zwątpienie dotyczy zapewnień Prusa, że jedynym właściwym odniesieniem tytułu powieści jest lalka Heluni Stawskiej. Chodzi o odpowiedź autora Faraona na głosy krytyki utożsamiające tytuł powieści z postacią Izabeli Łęckiej.,Panna Izabela nie jest 'lalką' (lalką - jest lalka Heluni Stawskiej)”3.

1 M.Płachecki, Sto zdaño Wokulskim, http://serwer1401583.home.pl/74PlaMSt.pdf (stan z 1.04.2016)

2 Zob. G. Wołowiec, Samokrytyka pisarza jako gatunek wypowiedzi, w: Genologia dzisiaj, red.W. Bolecki i I. Opacki, Warszawa 2000.

3 B. Prus, Stówko o krytyce pozytywnej, w zbiorze: Polska krytyka literacka (1800-1918). Materiaty, t. 3, red. J. Krzyżanowski, przygotowali J. Kulczycka-Saloni [i in.], Warszawa 1959, s. 88. 
To samo podkreślał w liście do „Kuriera Warszawskiego”, pisząc o wdzięczności dla przypadkowo przeczytanej notki prasowej o kradzieży lalki.

Wydało mi się to nieco niezdarną próbą sterowania recepcją, ale dziś, po latach lektury wiem, że pisarz mówił prawdę i wszystkie inne objaśnienia tytułu są wobec tego podrzędne.

Powtórne zwątpienie wydaje się mniej poważne, dotyczy bowiem postaci, niemniej ten przypadek chcę omówić najpierw. Oto podczas lektury śmiałem się małodusznie z Ignacego Rzeckiego, kiedy ten sugerował Wokulskiemu, że wyrzuca z pracy subiekta Mraczewskiego z powodu różnic w poglądach politycznych. Tymczasem, dziś jestem przekonany, że diagnoza motywów postępowania pryncypała była zaskakująca, błyskotliwa i - co najważniejsza - prawdziwa.

\ Gdy panna Izabela weszła, młodzieniec oglądający laski poprawił kołnierzyk na szyi, dwie panienki spojrzały na siebie, pan Lisiecki urwał w połowie swój okrągły frazes o stylu kandelabrów, ale zatrzymał okrągłą pozę, a nawet dama słuchająca jego wykładu ciężko odwróciła się na krześle. Przez chwilę sklep zaległa cisza, którą dopiero panna Izabela przerwała odezwawszy się pięknym kontraltem:

- Czy zastałyśmy pana Mraczewskiego?...

- Panie Mraczewski!... - pochwycił pan Ignacy.

Mraczewski już stał przy pannie Izabeli, zarumieniony jak wiśnia, pachnący jak kadzielnica, z pochyloną głową, jak kita wodnej trzciny.

- Przyszłyśmy prosić pana o rękawiczki.

- Numerek pięć i pół - odparł Mraczewski i już trzymał pudełko, które mu nieco drżało w rękach pod wpływem spojrzenia panny Izabeli.

- Otóż nie... - przerwała panna ze śmiechem. - Pięć i trzy czwarte... Już pan zapomniał!...

- Pani, są rzeczy, których się nigdy nie zapomina. Jeżeli jednak rozkazuje pani pięć i trzy czwarte, będę służył w nadziei, że niebawem znowu zaszczyci nas pani swoją obecnością. Bo rękawiczki pięć i trzy czwarte - dodał z lekkim westchnieniem, podsuwając jej kilka innych pudełek - stanowczo zsuną się z rączek...

- Geniusz! - cicho szepnął pan Ignacy mrugając na Lisieckiego, który pogardliwie ruszył ustami

4 B.Prus, Lalka, oprac. J. Bachórz, (BN I 262), Wrocław 1991, t. 1, s. 124-125. Dalsze cytaty z powieści opatrzone literą „L” oraz numerami tomów i stron podaję na podstawie tej edycji. 
Scena omal nie doprowadza Wokulskiego do wybuchu, zwłaszcza, że po wyjściu Izabeli, Mraczewski pozwala sobie na niedwuznaczne komentarze, w rodzaju:

1) Matyldy są na co dzień, damy na święta. Ale Iza będzie największym świętem. Słowo honoru daję, że nie znam kobiety, która by na mnie tak piekielne robiła wrażenie... No, ale bo też i ona lgnie do mnie! (L, t. I, s. I3O)

Nie wybucha jednak, tylko wychodzi ze sklepu. Cały kolejny, znakomity, gęsty od obrazów i znaczeń, rozdział Medytacje jest oparty na przeplataniu się brutalnej krytyki społecznej (spacer po Powiślu), z syntetycznym skrótem biografii Wokulskiego, która zyskała dlań sens w chwili, kiedy ujrzał w teatrze Izabelę.

Ale jest i trzeci składnik wielowątkowej narracji tego rozdziału: natrętnie powracający epizod z Mraczewskim. Spacer nie przynosi bohaterowi ukojenia.

》 Wokulski zamknął księgę i włożył ją do kantorka. W tej chwili znowu weszły do sklepu trzy panie żądając rękawiczek.

Targ z nimi przeciągnął się z kwadrans. Wokulski siedział na fotelu i patrzył w okno; gdy zaś damy wyszły, odezwał się tonem bardzo spokojnym:

- Panie Mraczewski.

- Co pan każe?... - spytał piękny młodzieniec biegnąc do kantorka krokiem kontredansowym.

- Od jutra niech pan postara się o inne miejsce - rzekł krótko Wokulski.

Mraczewski osłupiał.

- Dlaczego, panie szefie?... Dlaczego?...

- Dlatego, że u mnie już pan nie ma miejsca.

- Jakiż powód?... Przecie chyba nic złego nie zrobiłem? Gdzież pójdę, jeżeli pan tak nagle pozbawi mnie posady?

- Świadectwo dostanie pan dobre - odparł Wokulski. - Pan Rzecki wypłaci panu pensję za następny kwartał, wreszcie - za pięć miesięcy... A powód jest ten, że ja i pan nie pasujemy do siebie... Zupełnie nie pasujemy. - Mój Ignacy, zrób z panem Mraczewskim rachunek do pierwszego października.

To powiedziawszy Wokulski wstał z fotelu i wyszedł na ulicę.

[...]

Dopiero około piątej po południu zbliżył się do Wokulskiego Rzecki. Oparł ręce na kantorku i rzekł półgłosem: 
- Matka tego Mraczewskiego, Staśku, jest bardzo biedna kobieta...

- Zapłać mu pensję do końca roku - odparł Wokulski.

- Myślę... Stasiu, myślę, że nie można aż tak karać człowieka za to, że ma inne niż my przekonania polityczne...

- Polityczne?... - powtórzył Wokulski takim tonem, że panu Ignacemu przeszedł mróz po kościach... (L, t. I, s. I62-163)

Tu właśnie zachichotałem z Rzeckiego śmiechem Rzeckiego („Hi, hi, hi”). Przecież powód jest jasny dla każdego czytelnika i nie wiadomo czemu pan Ignacy nie widzi zazdrości Stacha o umizgi Mraczewskiego. A już zupełnie nie mogłem sobie wyobrazić, że można wymyśleć tak absurdalną motywację, jak poglądy polityczne. Myliłem się jednak, bo pan Ignacy widzi wszystko, uczył się wszak od starego Mincla, który spoza zamkniętych powiek widział na podłodze rodzynkę, która potem znalazła się w ustach Ignasia. Widzi zatem i rozumie najdalsze konsekwencje „gry w rękawiczki”. Pięciokrotny powrót natrętnego szczegółu sprawia, że ten potężnieje w umyśle zakochanego Stacha w fetysz symbolizujący upragniony obiekt; fetysz, któremu na imię rękawiczki. Zbierzmy jeszcze raz wszystkie natrętne powroty tego elementu garderoby w tym epizodzie:

II. - Dlaczego, Belciu, do Wokulskiego? - zapytała trochę zdziwiona panna Florentyna.

- Chcę sobie kupić paryskie rę ka wi c zk i, kilka flakonów perfum...

- To samo dostaniemy gdzie indziej.

- Chcę tam - odpowiedziała sucho panna Izabela.

2. - Cóż to za sklep budują? - spytała panny Florentyny.

- Chyba dla Wokulskiego, bo słyszałam, że wziął obszerniejszy lokal.

„Dla mnie ten sklep!” - pomyślała panna Izabela szarpiąc rę k a wiczki.

3. Mraczewski już stał przy pannie Izabeli, zarumieniony jak wiśnia, pachnący jak kadzielnica, z pochyloną głową, jak kita wodnej trzciny.

- Przyszłyśmy prosić pana o rękawiczki.

- Numerek pięć i pół - odparł Mraczewski i już trzymał pudełko, które mu nieco drżało w rękach pod wpływem spojrzenia panny Izabeli.

- Otóż nie... - przerwała panna ze śmiechem. - Pięć i trzy czwarte... Już pan zapomniał!... 
- Pani, są rzeczy, których się nigdy nie zapomina. Jeżeli jednak rozkazuje pani pięć i trzy czwarte, będę służył w nadziei, że niebawem znowu zaszczyci nas pani swoją obecnością. Bo rę ka wi c zk i pięć $\mathrm{i}$ trzy czwarte - dodał $\mathrm{z}$ lekkim westchnieniem, podsuwając jej kilka innych pudełek - stanowczo zsuną się z rączek...

4. Po szpakowatym jegomościu weszła do sklepu dama żądająca parasola, później pan w średnim wieku chcący nabyć kapelusz, potem młody człowiek żądający cygarnicy, nareszcie trzy panny, z których jedna kazała podać sobie rę kawiczki Szolca, ale koniecznie Szolca, bo innych nie używa.

5. Wokulski zamknął księgę i włożył ją do kantorka. W tej chwili znowu weszły do sklepu trzy panie żądając rękawiczek. Targ z nimi przeciągnął się z kwadrans. Wokulski siedział na fotelu i patrzył w okno; gdy zaś damy wyszły, odezwał się tonem bardzo spokojnym:

- Panie Mraczewski.

- Co pan każe?... - spytał piękny młodzieniec biegnąc do kantorka krokiem kontredansowym.

- Od jutra niech pan postara się o inne miejsce - rzekł krótko Wokulski [wyróżn. R. K.].

Powracający motyw rękawiczek - już bez Izabeli - staje się dla niego fetyszem, czyli nasyconym symboliczną treścią przedmiotem, który jest synekdochą kompletnego obiektu pragnienia 5 . Pięć razy dla czytelnika, a tylko trzy powroty natrętnego fetysza dla Wokulskiego („do trzech razy sztuka”) okazują się nie do zniesienia. Głosy klientów wypowiadających przeklęte słowo „rękawiczki” nie pozwalają zapomnieć o Mraczewskim i Izabeli „połączonych” rękawiczkami. Scena, a jest to odmiana „sceny pierwotnej”, musi zostać zniszczona, choć nie da się jej usunąc z pamięci, a na dodatek powtórzy się ona w pociągu do Krakowa.

Prus pozwolił Rzeckiemu w genialnej intuicji rozpoznać w Wokulskim fetyszystę, któremu nieobecny lub nieosiągalny obiekt pragnienia kondensuje się $\mathrm{w}$ przedmiocie - tu: w rękawiczkach. Już dialog Izabeli z Marczewskim jest dla Wokulskiego

5 Warto wspomnieć w tym miejscu - na prawach kontekstu kulturowego - o intrygującej zbieżności fascynacją tym elementem kobiecego ubioru oddaną w sztuce lat osiemdziesiątych XIX w.: cyklu 10 akwafort zatytułowanym Rękawiczka (Ein Handschuch) autorstwa Maxa Klingera, powstałym w 1881 r. Wyobraża on fantastyczne marzenia senne artysty, zakochanego w nieznajomej, której symbolem staje się upuszczona przez nią rękawiczka - znajdowana, tracona, porywana, adorowana (zob. art-bin.com/art/klingertexts/klinger1 (stan z 10 grudnia 2015 r.)). 
prawie nie do zniesienia, ale przesilenie następuje, kiedy anonimowe klientki „żądają rękawiczek". Powrót nazwy fetysza brukanego wcześniej rękami profana sprawia, że Wokulski wybucha i usuwa bluźniercę i rywala w jednej osobie. Słusznie zwracał uwagę Jakub Malik na zhierarchizowanie mikroświata sklepu, w którym „na dole drabiny społecznej są uczniowie, nad nimi pomocnicy subiektów, subiekci, saldokontyści, buchalterzy, a nad wszystkim czuwa pryncypał wszechwładny w swoich decyzjach”. Niemniej, sam Wokulski jest dowodem, że sukces finansowy lub zwykłe małżeństwo dla pieniędzy może błyskawicznie zmienić ową hierarchię. Towar, poprzez jego bliskość i namacalność, jest obietnicą, że wszystko jest w zasięgu ręki, także człowiek, który przedmiotów tych używa lub ich pragnie. Fetyszyzm erotyczny odkrywa w świecie towarów doskonałe środowisko rozwoju, a w tej konkretnej scenie prowadzi do zrównania subiekta i pryncypała, który wszak też był jeszcze niedawno subiektem.

Zanim jednak dotrzemy do związku fetyszyzmu erotycznego z politycznym uzasadnieniem wyrzucenia Mraczewskiego z pracy, warto dokonać krótkiej przechadzki po rozległych obszarach dziewiętnastowiecznego fetyszyzmu, w tej epoce bowiem co najmniej trzy dyskursy rościły sobie doń prawo: antropologiczno-filozoficzny, ekonomiczny i psychoanalityczny. Wszystkie one rozbrzmiewają lub raczej szemrzą w sklepie „J. Mincel i S. Wokulski”.

Słowo „fetysz” pochodzi z języka portugalskiego, tak bowiem: feitiço, kupcy nazwali przedmioty, które Afrykańczycy uważali za magiczne. Etymologię łacińską oraz proces adaptacji tego terminu w językach europejskich omówił Peter Melville Logan?.

W słowniku pozytywistów pojęcie to pojawia się wcześnie, u samego zarania, mianowicie w Kursie filozofi pozytywnej (1830-1842) Augusta Comte’a. Twórca pozytywizmu stworzył tam słynne prawo trzech stadiów postępu w objaśnianiu rzeczywistości, które to prawo miało dowieść nieuniknionego panowania pozytywizmu nad światem. W globalnym procesie akumulacji wiedzy fetyszyzm był pierwszą fazą pierwszego stadium: teologicznego.

Często jednak zapominamy, że Comte nie uważał fetyszyzmu za archaiczną przeszłość Zachodu, ale za sposób postrzegania rzeczywistości, który pojawia się „do dziś dnia wśród olbrzymiej większości białej rasy, choć występuje obecnie z nierównym natężeniem i pod postaciami różnymi, a nawet zgoła niezgodnymi ze sobą" ${ }^{\prime}$. Oznacza to, że nowoczesny, racjonalnie wyedukowany umysł nadal przy-

6 J. Malik, „Lalka”. Historie z różnych światów, Lublin 2005, s. 27.

7 P. M. Logan, Victorian Fetischism. Intellectuals And Primitives, New York 2009, s. 18-29.

8 A. Comte, Rozprawa o duchu filozofii pozytywnej, w: idem, Rozprawa o duchu filozofii pozytywnej. Rozprawa o catoksztatcie pozytywizmu, tłum. B. Skarga, Warszawa 1973, s. 7. 
pisuje naturze lub przedmiotom istnienie i działanie intensywniejsze, niż istnienie i działanie ludzkie. Skutkiem tego nawet umysł człowieka epoki pozytywnej „łączy się w sposób nierozerwalny z całokształtem poprzedzających go stanów [...]. Najwybitniejsi myśliciele stwierdzić mogą w sobie naturalną skłonność do zgoła naiwnego fetyszyzmu, ilekroć niewiedzy ich towarzyszy chwilowo jakieś wyraźne wzruszenie" 9 . I jeszcze jedno zaskoczenie - zdaniem Comte'a, fetyszyzm jako dyspozycja umysłu ma zdecydowanie korzystny walor, który przejawia się w postaci aktywnego dziedzictwa ludzkości u pojedynczych jednostek. Taką fazą rozwojową przepełnioną konstruktywnym fetyszyzmem jest dzieciństwo każdego człowieka.

》W tym wieku filozofia jednostki, podobnie jak i gatunku ludzkiego, w odpowiedniej fazie ogranicza się do czystego fetyszyzmu, którego naturalny rozwój nie powinien być zakłócany przez żadną zbędną interwencję ${ }^{\mathrm{IO}}$.

Comte, jak widać, nie absolutyzuje poznania naukowego, wykluczając $z$ fazy pozytywnej regresywne pozostałości faz wcześniejszych.

\Przeciwnie zaś, pozytywizm zajmując zawsze stanowisko relatywistyczne, przyjmuje taką teorię historii, która umożliwi obserwacje ludzkiego życia we wszystkich jego postaciach [...]. Poeta pozytywny [...] może wżyć się w każdą epokę tak dalece, że wzbudzi naszą sympatię dla dowolnego okresu; każdy z nas winien w sobie samym odnaleźć dlań samorzutny oddźwięk ${ }^{\mathrm{II}}$.

Podkreślmy raz jeszcze: Comte, na długo przed Freudem, uznaje fetyszyzm nie za objaw prymitywizmu, zabobonu czy patologii, ale za powszechny składnik nowoczesnego umysłu; aktywną w nim pozostałość dzieciństwa i archaicznego dziedzictwa ludzkości. Przednaukowym dyskursem, który ujawniał od dawna ten aspekt ludzkiego umysłu jest wg Comte’a (jak i według Freuda czy Vico) poezja ${ }^{\text {I2 }}$.

$9 \quad$ Ibidem

10 A. Comte, Rozprawa o catoksztatcie pozytywizmu, w: Rozprawa o duchu flozofi pozytywnej..., op. cit., s. 329 .

11 Ibidem, s. 480.

12 Na przykład taki „poeta pozytywny”, jak Stanisław Witkiewicz, pisze: „Wszystkie potoczki i potoki, siklawy, wodospady i wywietrzyska mieszają swoje głosy, przełamują je echami o ściany turni, uderzają o drzewa lasów i zdradnie się śmieją i wabią człowieka." (S. Witkiewicz, Na przetęczy, w: idem, Pisma zebrane, t. III: W kręgu Tatr, Kraków 1970, s. 112). 
Comte określa poznawczą, sensotwórczą, terapeutyczną funkcję fetysza jako zdolność podmiotu do nadawania sensu całości zjawisk zewnętrznych wobec niego, które dzięki fetyszowi tracą swoją chaotyczną przypadkowość. Dzieje się tak, ponieważ wiara w fetysz sprawia, że wyobrażenia dominują nad faktami, przez co rzeczywistość przybiera formę permanentnej halucynacji ${ }^{13}$. Tak myśli o swoim życiu Wokulski po spotkaniu Izabeli:

》 Uczuć swoich nie nazwałby miłością i w ogóle nie był pewny, czy dla oznaczenia ich istnieje w ludzkim języku odpowiedni wyraz. Czuł tylko, że stała się ona jakimś mistycznym punktem, w którym zbiegają się wszystkie jego wspomnienia, pragnienia i nadzieje, ogniskiem, bez którego życie nie miałoby stylu, a nawet sensu. Służba w sklepie kolonialnym, uniwersytet, Syberia, ożenienie się z wdową po Minclu, a w końcu mimowolne pójście do teatru, gdy wcale nie miał chęci - wszystko to były ścieżki i etapy, którymi los prowadził go do zobaczenia panny Izabeli (L, s. I40-I4I).

Aby ująć ten aspekt miłości Wokulskiego w języku epoki, należy opuścić dyskurs antropologizującej filozofii Comte’a i przenieść się na grunt psychologii, która przejęła pojęcie fetyszyzmu dla opisu zagadnień $z$ kręgu psychologii atrakcji. Ale i tu naukę wyprzedza literatura, bowiem jak podaje Logan - fetysz w znaczeniu erotycznym pojawia się w powieści Nicolasa Rétifa de la Bretonne’a (I734-I806) pod tytułem Historie des compagnes de Maria (I8II r.), w której autor porównuje erotyczne oddziaływanie kobiecych butów do fetyszów z Nowej Gwinei ${ }^{\mathrm{I} 4}$. Do literatury medycznej fetyszyzm seksualny wprowadził Jean Étienne Esquirol, francuski lekarz, który w swoim Stowniku nauk medycznych uczynił fetyszyzm odmianą m o n o m a n i [wyróżn. R. K.], dysfunkcji psychicznej, która nie musi przeszkadzać w normalnym życiu, jest bowiem wąską fiksacją, która czasem staje się niebezpieczna. Szczególną odmianą jest monomania erotyczna, czyli „obłędna czułość” skierowana ku osobie lub przedmiotom nieożywionym. Jest to - jak pisze - „sport wyobraźni”'

Próbując zrozumieć postawę Eweliny wobec barona, Wokulski, z pomocą narratora, diagnozuje siebie właśnie jako monomaniaka:

\ „Oczywiście coś jej strzeliło do głowy i musi być także zadurzona, jeżeli nie w jego wdziękach, to w stanowisku. Inaczej musiałaby zdradzić

13 P. M. Logan, op. cit., s. 36.

14 Ibidem, s. 117.

15 Ibidem, s. 116. 
się, że gra komedię, a baron musiałby spostrzec to, bo miłość patrzy przez mikroskop. A jeżeli młoda dziewczyna może pokochać takiego dziada, to dlaczegóż by mnie nie miała pokochać tamta?...”

„Zawsze wracam do swego! - szepnął. - Ta myśl stała się już rodzajem monomanii...” (L, t. II, s. I79)

Dopiero Alfred Binet, uczeń Jeana-Martina Charcota, uczynił fetyszyzm terminem technicznym dla opisu patologii seksualnej. W artykule: Le fetichisme dans l'amour („Revue Philosophique” 1887; przedrukowany w: A. Binet, Etudes de psychologie experimentale 1888) uzasadnił używanie tej kategorii w odniesieniu do wszelkich form erotycznego zainteresowania przedmiotami. Uważał fetyszyzm za chorobę dojrzałej cywilizacji, która osiągnąwszy kres, wraca do swoich barbarzyńskich źródeł. Wybór przedmiotu wynikał z erotycznych skojarzeń, których źródeł upatrywał w dzieciństwie.

Najbardziej wpływową książką z zakresu seksuologii przed Freudem była Psychopatia Sexualis Richarda von Krafft-Ebinga (pierwsze wydanie pochodzi z I886 r.). Ale, jak podaje Logan, dopiero Io wydanie z 1898 r. zawiera szerokie omówienie tego zjawiska, które u Krafft-Ebinga urasta do rangi fundamentu wszelkiej ludzkiej seksualności - normalnej i patologicznej ${ }^{\mathrm{j}}$. Powszechność fetyszyzmu wywodził z jego służebnej funkcji stymulowania prokreacji, był on więc wyrazem adaptacyjnej skuteczności ludzkiego gatunku. Zdaniem Krafft-Ebinga nikt nie jest wolny od jego łagodnej postaci:

\Dla normalnego człowieka pogrążonego w ekstatycznej miłości chusteczka, but, rękawiczka, list, darowany kwiat, kosmyk włosów, itp. może stać się obiektem czci, ale tylko dlatego, że reprezentuje pamiętany symbol ukochanej osoby - nieobecnej lub martwej - której cała osobowość jest w nim odtworzona. Fetyszysta patologiczny nie buduje relacji symbolicznej z przedmiotem, wystarcza mu on sam jako obiekt erotyczny ${ }^{\mathrm{I}}$.

Wszyscy jesteśmy zatem fetyszystami, dla większości to zachowanie jest instrumentem fantazjowania o nieosiągalnym obiekcie pragnienia, a tylko niektórym wystarcza sam przedmiot. Ci ostatni są według Krafft-Ebinga nieszczęśnikami torturowanymi przez tę skłonność, co ilustruje np. „przypadek I22, Pan Z.33-letni Amerykanin, przedsiębiorca, od 8 lat szczęśliwie żonaty, obdarzony potomstwem,

16 Ibidem, s. 118-119.

17 R.von Krafft-Ebing, Psychopatia Sexualis, s. 221, cyt. za: P.M. Logan, op. cit., s. 122. 
ale cierpiący na dziwaczny i kłopotliwy «fetyszyzm rękawiczkowy». Pogardzał sobą z tego powodu i twierdził, że znajduje się na skraju rozpaczy, a nawet szaleństwa"”8

W Lalce jest nieporównanie ciekawiej, ponieważ wzorcową wylęgarnią fetyszyzmu uczynił autor sklep. Gdybyż to była monomania, prywatna udręka zakochanego podmiotu! Prus dzięki Mraczewskiemu pokazuje, że fetyszyzm Wokulskiego nie jest szczególny, ale powszechny za sprawą powszechnej ekonomizacji życia. Rękawiczki Izabeli, to nie rękawiczka ze słynnej ballady Schillera, którą tylko jeden Emrod może podjąć spomiędzy dzikich bestii. Rękawiczki Izabeli są dla każdego, kogo na nie stać. Wokulski chciałby być bohaterem Schillera, niestety, łącząc z konieczności erotyzm i ekonomię, z fetyszysty erotycznego staje się fetyszystą towarowym. Sama Izabela też pojmuje niejasno ten splot ekonomii kapitalistycznej i erotyzmu. Zdejmując i zakładając rękawiczki podejmuje z Wokulskim grę w fetysze. Nie twierdzi, że nie jest na sprzedaż - tylko że jest bardzo droga. Intuicyjnie wie, że na giełdzie matrymonialnej Wokulski zapłaci najwięcej, bo wybranka jest dla niego obietnicą czegoś więcej niż towar. Co to za obietnica?

Marks w pierwszym tomie Kapitatu pomieścił niezwykłe, mistyczne niemal, rozważania o fetyszyzmie towarowym:

\Towar wydaje się na pierwszy rzut oka rzeczą samą przez się zrozumiałą i trywialną. Analiza wykazuje, że jest to rzecz diabelnie zawikłana, pełna metafizycznych subtelności i kruczków teologicznych. Jako wartośc użytkowa nie zawiera towar nic tajemniczego, wszystko jedno, czy spojrzę nań z tego punktu widzenia, że dzięki swym własnościom zaspokaja ludzkie potrzeby, czy z tego, że własności tych nabywa dopiero jako produkt ludzkiej pracy. [...]

Skąd więc pochodzi zagadkowy charakter produktu pracy z chwilą gdy przybiera formę towaru? Oczywiście z tej formy właśnie. [...] Tajemniczość formy towarowej polega więc po prostu na tym, że odzwierciedla ona ludziom społeczny charakter ich własnej pracy jako przedmiotowy charakter samych produktów pracy [...]. Natomiast forma towarowa i stosunek wartościowy produktów pracy, w którym ona znajduje wyraz, nie ma absolutnie nic wspólnego z ich fizyczną naturą i z wynikającymi z niej rzeczowymi stosunkami. To tylko określony stosunek społeczny między samymi ludźmi przyjmuje tu dla nich ułudną postać stosunku między rzeczami. Aby więc znaleźć analogię, trzeba się przenieść w mgławice świata religii. Tu produkty ludzkiej głowy wydają się obdarzone własnym życiem, samodzielnymi 
postaciami, pozostającymi w stosunkach z sobą i z ludźmi. Podobnie dzieje się w świecie towarów z produktami ludzkiej ręki. Nazywam to fetyszyzmem, który przylgnął do produktów pracy, odkąd są wytwarzane jako towary i jest nieodłączny od produkcji towarowej ${ }^{\mathrm{I}}$.

Indywidualna mania Wokulskiego zostaje uspołeczniona w przedmiocie-rękawiczce jako formie społecznej, czyli towarze wytwarzanym, sprzedawanym pośrednikowi i ponownie sprzedawanym w sklepie. Cyrkulacja fetysza-rękawiczki obciąża ją znaczeniami należącymi do sprzecznych, ale istniejących równocześnie, porządków symbolicznych. Wokulski nie jest patologicznym fetyszystą erotycznym czy towarowym, ponieważ sam fetysz go nie zaspokaja, pragnie całości, którą fetysz obiecuje. To Izabela, powtarzając, że nie jest na sprzedaż, mówi w istocie: „Kup mnie wreszcie". Cała arystokracja w Lalce cierpi na impotencję własnych, ekstensywnych kapitałów, unieruchomionych w archaicznych formach gospodarowania. Stąd widzi w Wokulskim fetysza nowoczesnego świata; fetysza, który zarówno ich pobudzi, jak i objaśni nową rzeczywistość.

Epizod z rękawiczkami brutalnie objawił polityczną stronę ekonomii w powieści. Umysł zakochanego czci fragment ubioru ukochanej i niedostępnej kobiety, który należy wyłącznie do niego (podarowany, zdobyty, skradziony) i obiecuje, na zasadzie pars pro toto, nadejście upragnionego dopełnienia. Kiedy jednak każda rzecz, najbardziej nawet intymna, nosi na sobie piętno towaru, wówczas fetyszysta słusznie podejrzewa, że metafizyczne źródło jego „czułego obłędu” jest naprawdę powszechną chorobą cywilizacji, jak twierdził Binet.

Wspaniała intuicja Rzeckiego odsłoniła wielowymiarowość fetyszyzmu Wokulskiego, w tym także jego polityczność. Oto, jak pisał już Comte, można być podmiotem sceptycznym, a zarazem wyznawcą obiektu, który równocześnie się czci i demistyfikuje. Nowoczesny fetyszysta jest po części wyznawcą, a po części krytykiem własnego pożądania. Wokulski odkrywając społeczne, biologiczne, kulturowe (w tym klasowe i ekonomiczne) źródła idealizacji Izabeli, wcale nie przestaje jej czcić. Chcąc zobiektywizować jej wyjątkowość bez skrupułów używa ekonomicznej przewagi nad Mraczewskim, aby zachować nietykalność obiektu, ze skutkiem żałosnym, jak wiemy. Ekonomia kapitalizmu wpłynęła istotnie na dynamikę fetyszyzmu, którym jest odtąd przede wszystkim sam kapitał. Ten jednak, jak pouczał Marks, ,niszczy aureolę świętości...”20.

19 K. Marks, Kapitat. Krytyka ekonomii politycznej, tom I, Rozdział I. Towar. 4. „Fetyszyzm towarowy i jego tajemnica”, http://sady.up.krakow.pl/antfil.marx.kapital.htm (stan z 10 grudnia 2012 r.).

20 W jaki sposób dotknęło to samego Prusa jako artysty, pokazał w świetnej analizie Ireneusz Gielata w rozdziale Nowoczesny artysta na rynku pracy, w swojej książce: Bolestaw Prus na progu nowoczesności, Bielsko-Biała 2011, s. 97-117. 
Teraz mogę wrócić do mojego pierwszego zwątpienia, czyli jak to nie wierzyłem Prusowi, gdy zapewniał, że w kompozycji powieści liczy się tylko lalka Heluni Stawskiej. Zaczerpnięta z prasy wzmianka o procesie w sprawie kradzieży lalki stała się u Prusa wspaniałym, pulsującym znaczeniami motywem, które to pulsowanie przytłumimy nieco dla zachowania związku z wcześniejszą analizą motywu rękawiczek. Scena, jak to nierzadko u Prusa, opiera się na zabawnym przekształceniu klasycznego motywu, tu: starotestamentowego wyroku Salomona. W procesie nie idzie bowiem wyłącznie o kradzież. Sąd, w oczach czytelnika, ma także zadośćuczynić cierpieniu. Jest to orzeczenie o prawie własności, ale także o tym, kto bardziej cierpi, a przez to bardziej kocha lalkę, ów substytut obiektu żałoby. Wszak baronowa cierpi po stracie córeczki, a obie Stawskie po stracie ojca i męża. Inaczej niż biblijny Salomon, sędzia w Lalce rozcina jednak sporne „dziecko”.

》S Sędzia wziął do rąk lalkę, która tyle narobiła zgryzoty, i urzędowym scyzorykiem rozciął jej naprzód stanik, a następnie począł z wielką uwagą odpruwać głowę od tułowia. Helenka, z początku zdziwiona, przypatrywała się tej operacji, następnie zwróciła się do matki mówiąc półgłosem:

- Mamo, dlaczego ten pan rozbiera Mimi? Przecież ona będzie się wstydzić...

Nagle zrozumiawszy, o co chodzi, wybuchnęła płaczem i kryjąc twarz w suknię pani Stawskiej, zawołała:

- Ach, mamo, po co on ją kraje?... To strasznie boli... O mamo, mamo, już nie chcę, ażeby Mimi krajali...

- Nie płacz, Heluniu, Mimi będzie zdrowa i jeszcze ładniejsza uspakajał ją Wokulski, wzruszony nie mniej od Helenki.

Tymczasem głowa Mimi spadła na papiery. Sędzia spojrzał wewnątrz i podając maskę pani baronowej rzekł:

$-\mathrm{Nu}$, niech pani przeczyta, co tam napisano?

Baronowa przycięła usta i milczała.

- To niech pan Maruszewicz przeczyta głośno, co tam jest.

- Jan Mincel i Stanisław Wokulski... - jęknął Maruszewicz (L, t. II, s. 333-334).

O prawie do obiektu, nawet obiektu miłości, rozstrzyga sygnatura towaru, stygmat handlowy, kwit sprzedaży. Lalka, która jest dla walczących kobiet substytutem straty, zostaje przywrócona rzeczom, a miłość i cierpienie opanowane przez kupiecką sprawiedliwość. A jednak pchają się symbole i alegorie: agresywne, nachalne, atrakcyjne i sugestywne. A gdyby jednak lalka była imieniem fantazmatu Wokulskiego, to kto 
ma do „niej” prawo? Czyją własnością jest miłosne marzenie bohatera? Napis ukryty we wnętrzu lalki bezlitośnie głosi, że zakochany bohater ma zawsze wspólnika... $\mathrm{w}$ interesach, a jego imię jest Pieniąd $z^{2 \mathrm{I}}$.

\section{Bibliografia:}

Comte A., Rozprawa o duchu filozofii pozytywnej, w: idem, Rozprawa o duchu filozofii pozytywnej. Rozprawa o catoksztatcie pozytywizmu, tłum. B. Skarga, Warszawa 1973;

Gielata I., Bolestaw Prus na progu nowoczesności, Bielsko-Biała 2011

Logan P. M., Victorian Fetischism. Intellectuals And Primitives, New York 2009;

Malik J.A., „Lalka”. Historie z różnych światów, Lublin 2005;

Marks K., Kapitat. Krytyka ekonomii politycznej, tom I, rozdz. I. Towar, 4. Fetyszyzm towarowy i jego tajemnica, http://sady.up.krakow.pl/antfil.marx.kapital.htm (stan z 10 grudnia 2012 r.);

Prus B., Lalka, oprac. J. Bachórz, (BN I 262), Wrocław 1991;

Prus B., Stówwko o krytyce pozytywnej, w zbiorze: Polska krytyka literacka (1800-1918). Materiaty, t. 3, red. J. Krzyżanowski, przygotowali J. Kulczycka-Saloni [i in.], Warszawa 1959;

Witkiewicz S., Na przetęzy, w: idem, Pisma zebrane, t. III: W kregu Tatr, Kraków 1970;

Wołowiec G., Samokrytyka pisarza jako gatunek wypowiedzi, w: Genologia dzisiaj, red. W. Bolecki i I. Opacki, Warszawa 2000.

SŁowA KLUCzE: Lalka, monomania, fetyszyzm, ekonomia

\section{Ryszard KozioŁeK}

\section{DOLLS' POLITICAL ECONOMY}

The article uses the concept of Marx's commodity fetishism to uncover and describe complex relations between eroticism, political economy and psychology in The Doll [Doll] by Bolesław Prus. The scene under analysis is when Wokulski fires from his shop a shop assistant who was overfamiliar with Izabela Eęcka. The interpretation applying the given contexts unveils political dimension of economy which Wokulski uses to overcome class barriers and also to create new boundaries which are supposed to separate the object of his love from other men.

KEY worDs: Lalka [Doll], monomania, fetishism, economy

21 Etymologia nazwiska Mincel - münze ('moneta'), zob. J.A. Malik, „Lalka”. Historie z różnych światów, Lublin 2005, s. 39. 